\title{
Effect of Ginkgo biloba Leaves Aqueous Extract on Carbon Tetrachloride Induced Acute hepatotoxicity in rats
}

\author{
Hala A.H. Khattab \\ Nutrition and Food Science Dept., Faculty of Home Economics, Helwan University
}

\begin{abstract}
Bachground: Oxidative stress plays a pivotal role in the pathogenesis and progression of various liver diseases. Ginkgo biloba leaves extract (GbE) have been proved to be an effective antioxidant, thereby can contribute to the prevention and treatment of diseases associated with oxidative stress. The present study aimed to investigate the hepatoprotective effect of $\mathrm{GbE}$ on acute liver injury induced using carbon tetrachloride $\left(\mathrm{CCl}_{4}\right)$ in rats.
\end{abstract}

Material and Methods: Hepatotoxicity was induced in male rats by intraperitoneal (i.p) injection of $\mathrm{CCl}_{4}$ $1 \mathrm{~mL} / \mathrm{kg}$ body weight (b.w.) for every $72 \mathrm{~h}$ for 14 days, $\mathrm{GbE}$ was administered orally at a dose of $150 \mathrm{mg} / \mathrm{kg}$ b.w., daily started two weeks prior to $\mathrm{CCl}_{4}$ injection and continued until the end of the experiment.

Results: $\mathrm{CCl}_{4}$ caused acute liver damage in rats, as evidenced by significant increase serum enzymes activities of aspartate and alanine aminotransferase (ALT \& AST) and alkaline phosphatase (ALP), and hepatic malondialdehyde (MDA), as well as significant decrease in weight gain percent, serum total protein (TP), high-density lipoprotein cholesterol (HDL-C), and hepatic reduced glutathione (GSH). Pretreatment with $\mathrm{GbE}$ prior to $\mathrm{CCl}_{4}$ injection elicited hepatoprotetcive activity by significant decreased the activities of liver enzymes and hepatic MDA, and significant increased the levels of TP, and hepatic GSH, as well as induced significant ameliorated in weight gain percent and lipid profile parameters as compared with $\mathrm{CCl}_{4}$ group. Histopathological examination of the liver tissues of $\mathrm{CCl}_{4}$ group represented the presence of hepatic necrosis associated with cells infiltration and vacuolar degeneration of hepatocytes, while the pretreatment with $\mathrm{GbE}$ overcome these changes, the majority of the cells tend to be normal.

Conclusion: The present findings indicated that the hepatoprotective effect of $\mathrm{GbE}$ against $\mathrm{CCl}_{4}$-induced oxidative damage may be due to its potent antioxidant activity. Therefore, GbE could be of potential help as a medicament or food supplement for alleviation of liver toxicity.

Key words: Ginkgo biloba - aqueous extract, male rats, carbon tetrachloride, liver enzymes, lipid parameters, malondialdehyde, reduced glutathione, hepatoprotective.

\section{Introduction:}

The liver, due to its metabolic enzymes, plays a vital role in maintaining the homeostasis of the body via the metabolism of endogenous and exogenous molecules and it eases their detoxification and elimination. Liver function can be impaired and hepatocytes damaged upon exposure to drugs, alcohol, infections, or malnutrition (Mroueh et al., 2004). It has been demonstrated that oxygen-derived free radicals and lipid peroxidation play a critical role in the pathogenesis of various liver diseases (Loguercio and Federico, 2003 and Das et al., 2005). Thereby, it has become the key to prevent and cure hepatic damage by eliminating free radicals

and preventing lipid peroxidation (Han et al., 2004 and Gedik et al., 2005), and are applied in clinical medicine (He et al., 2004).

Ginkgo biloba L. (Family: Ginkgoaceae), is an important herb medicine, achieving unprecedented popularity over the past decade, and the recognition of the important therapeutic effects shown by this plant (Guo et al., 2011). Chemically, the active constituents of Ginkgo biloba leaf are mainly (kaempferol, quercitin and isorhamnetin), diterpene lactones namely Ginkgolides A, B, C, M and $\mathrm{J}$ and bilobalide, biflavones (ginkgetin, isoginkgetin, bilobetin) and organic acids such as 4-hydroxybenzoic acid, that 
have presented various pharmacological activities (Ahlemeyer and Krieglstein, 2003 and Boonkaew and Camper, 2004). The extract of $G$.biloba leaves have been proved to be an effective antioxidant and found to possess cardioprotective, antiasthmatic, antidiabetic, and potent central nervous system activities, including enhancement of memory, concentration, mental alertness and decrease in mental fatigue (Naik et al., 2006 and Naik and Panda, 2007). Also, it is used in the management of cerebral insufficiency that occurs during normal aging and treatment of neurological diseases like Alzheimer's, dementia, and other cognitive dysfunctions (Kwon et al., 2004).

This extract has been shown several in vivo effects, including augmentation of blood flow and inhibition of platelet activating factor, it protects the cell membrane against damage induced by free radicals and presents protective effects against myocardial and brain ischemia/reperfusion injury (Zhang et al., 2000 and Ahlemeyer and Krieglstein, 2003). The herb in addition posses other important pharmacological actions. Ginkgo biloba extract decreased gastric injury caused by ethanol (Wang et al., 2000), protected against chemically induced oxidative injury and fibrosis (Ding et al., 2005). Therefore, the purpose of this study was designed to investigate the protective effect of $\mathrm{GbE}$ on $\mathrm{CCl}_{4}$-induced acute liver injury in rats.

\section{Material and Methods:}

\section{Drugs and chemicals:}

Carbon tetrachloride and liquid paraffin were purchased from Sigma Chemical Co. (St. Louis, MO, USA). Carboxymethl cellulose, Thiobarbituric acid, 1,1,3,3-tetramethoxypropane, trichloroacetic acid, and diethyl ether were obtained from Sigma-Aldrich (USA). Chemical Kits were obtained from Biodiagnostic Co. Egypt. All chemicals used were analytical grade of the highest laboratory purity. Casein was obtained from Misr Scientific Co. Dokki, Giza, Egypt. Cellulose and L-cystine were purchased from Morgan Co. Cairo, Egypt. Starch and corn oil were obtained from local market. Vitamins and minerals constituent and sucrose were obtained from El-Gomhoriya Pharm. and Chem. Ind. Co. Cairo, Egypt.

\section{Plant material:}

Ginkgo biloba L. family (Ginkgoaceae), leaves were obtained from International Garden, Abbas El-Akkad St., Nasr City, Cairo, Egypt. It was identified and collected by Agri. Eng. Mohammed Abdul Latif Jadallah, Director General of the International Garden. The plant leaf of Ginkgo biloba was confirmed by Prof. Dr. Al-Nowaihi, A. S. M., Prof. of Taxonomy, Botany Department, Faculty of Science, Ain Shams University.

\section{Preparation of aqueous extract of G. biloba:}

Ginkgo biloba leaves $(100 \mathrm{gm}$ dried powder) were soaked in 1 liter boiling distilled water. After $2 \mathrm{~h}$ it homogenized in the same distilled water, stirred by using magnetic stirrer at $40^{\circ} \mathrm{C}$ for $1 \mathrm{~h}$, then filtered through a two-layer of cheese cloth. The residue was re-extracted with fresh boiling distilled water by the same way. The later aqueous extract was added to the first one. This combined aqueous extract was condensed in rotary evaporator under vacuum then lyophilized and stored at $4{ }^{\circ} \mathrm{C}$ until further use according to Guo et al. (2011). Lyophilization was conducted at Mycotoxins Central Lab \& Food Safety, National Research Center, Dokki, Cairo by using Freeze-Dryer Lyophilizer Heidolph (Dura-TopDigital Programmer Bulk Tray Dryer FTSSystems, Dura-Dry MP, Egyptian Canadian Co. Laborota, 4000 efficient, $90 \mathrm{rpm}) .100 \mathrm{gm}$ of $G$. biloba L. leaves yielded 17.561 gm extract.

\section{Pretreatment with GbE:}

Ginkgo biloba extract was dissolved in carboxymethyl cellulose (CMC), and a dose of $150 \mathrm{mg} / \mathrm{kg}$ b.w. was administered by gavage in (1 $\mathrm{mL}$ of $1 \%$, w/v, CMC) according to Yapar et al. (2010).

\section{Induction of hepatotoxicity by $\mathbf{C C l}_{4}$ :}

Animals were injected intraperitoneally (i.p) with $\mathrm{CCl}_{4}(1 \mathrm{~mL} / \mathrm{kg}$ b.w., $1: 1 \mathrm{v} / \mathrm{v}$ mixture of $\mathrm{CCl}_{4}$ and liquid paraffin) every $72 \mathrm{~h}$ for 14 days according to Karthikeyan and Deepa (2010).

\section{Experimental animals:}

Forty-two adult male albino rats, Sprague Dawley strain, weighing $(170 \pm 10) \mathrm{g}$ were purchased from the animal house of the National Research Center, Dokki, Egypt. Animals were housed in plastic cages, fed on standard casein diet according to Reeves et al. (1993) and given 
tap water ad libitum. All rats were handled in accordance with the standard guide for the care and use of laboratory animals.

\section{Experimental design:}

After the period of adaptation (one week), animals were divided into four groups (each of 6 rats) as following: Control group: Rats were orally administered a single daily dose of $(1 \mathrm{~mL}$ of $1 \%$, w/v, CMC), after two weeks injected i.p. with liquid paraffin at a dose of $1 \mathrm{~mL} / \mathrm{kg} \mathrm{b}$. w. every $72 \mathrm{~h}$ for 14 days. $\mathbf{C C l}_{\mathbf{4}}$ group: Rats were injected i.p. with $\mathrm{CCl}_{4}$ in liquid paraffin $(1: 1)$ at a dose of $1 \mathrm{~mL} / \mathrm{kg}$ b.w. every $72 \mathrm{~h}$ for 14 days. GbE group: Rats were administered orally by gavage $\mathrm{GbE}$ at a dose of $150 \mathrm{mg} / \mathrm{kg}$ b.w. dissolved in (1 $\mathrm{mL}$ of $1 \%, \mathrm{w} / \mathrm{v}, \mathrm{CMC}$ ) for 28 days. Pretreated GbE group: Rats were administered orally with $\mathrm{GbE}$ at the same dose in GbE group, started two weeks prior to $\mathrm{CCl}_{4}$ injection and continued until the end of the experiment. During the experimental period, food intake was recorded daily, and all animals were weighed at the beginning and biweekly intervals to monitor changes and to adjust the dose of $\mathrm{GbE}$ and $\mathrm{CCl}_{4}$ accordingly.

\section{Blood collection and serum separation:}

Blood samples were withdrawn from the retro orbital plexu of each animal, $48 \mathrm{~h}$ after the last dose of the drug under anesthesia with diethyl ether according to the method of Cocchetto and Bjornsson (1983). Blood was allowed to clot, and then centrifuged at $3000 \mathrm{rpm}$ for $15 \mathrm{~min}$ to separate serum, which kept at $-20{ }^{\circ} \mathrm{C}$ till biochemical analysis. Immediately after blood sampling, animals were sacrificed and the liver of each animal was dissected out, a part of liver was fixed in $10 \%$ formalin for histopathological studies and the other part was washed with icecold saline to remove as much blood as possible and stored at $-20^{\circ} \mathrm{C}$ until assayed.

Determination of liver enzymes activities and total protein:

Separated serum samples were used for determination of alanine and aspartate aminotransferase activities (ALT\&AST) (Reitman and Frankel, 1957) and alkaline phosphatase (ALP) (Belfied and Goldberg,1971). Furthermore, serum samples were used for determination of total protein (TP) (Henry, 1964).

\section{Determination of lipid profile parameters:}

Serum samples were used for determination of triacylglycerol (TG) (Fossati and Prencipe, 1982), total cholesterol (TC) (Allain et al., 1974) and high-density lipoprotein cholesterol (HDL-C) (Demacker et al., 1980). While, low-density lipoprotein cholesterol (LDL-C) and very lowdensity lipoprotein cholesterol (VLDL-C) were calculated according to the equation of (Friedewald et al., 1972).

\section{Determination of hepatic malondialdehyde and reduced glutathione:}

Liver homogenized (10\%) was prepared in ice cold saline $(0.9 \%)$, and the homogenized tissues were centrifuged at $3000 \mathrm{rpm}$ at $4{ }^{\circ} \mathrm{C}$ for $30 \mathrm{~min}$. The obtained supernatants were used for determination of malondialdehyde (MDA) as a measure of lipid peroxidation (Yoshioka et al., 1979), and reduced glutathione (GSH) (Beutler et al., 1963).

\section{Histopathological examination:}

Specimens from liver were fixed immediately in $10 \%$ neutral buffered formalin, dehydrated in different grades of alcohol, cleared in xylol, embedded in paraffin wax, sectioned at 4-6 u thick and stained with Haematoxylin and Eosin (Bancroft et al., 1996) and examined microscopically.

\section{Statistical analysis:}

Results were expressed as a (mean $\pm \mathrm{SE}$ ). Data were analyzed statistically by analysis of variance, for statistical significance using L.S.D. test, one way ANOVA, post hoc multiple comparisons according to Snedecor and Cochron (1989). An IBM computer with a software system SPSS version 20 was used for these calculations.

\section{Results:}

\section{Biological evaluation:}

The result in Table (1) shows the effect of $\mathrm{GbE}$ on biological evaluation (weight gain percent, food intake and food efficiency ratio) in $\mathrm{CCl}_{4}$ intoxicated rats. It is observed that there was significant decrease in weight gain percent $(\mathrm{p}<$ $0.001)$, food intake $(p<0.001)$ and FER $(p<0.01)$ in $\mathrm{CCl}_{4}$ intoxicated group as compared to control group. Concerning the effect of $\mathrm{GbE}$ on rats, the ingestion showed slightly increase in weight gain percent, food intake and FER, there were no significant difference 
as compared with control group. Pretreatment of rats with $\mathrm{GbE}$ showed a significant increase in weight gain percent $(p<0.001)$, food intake $(p<0.001)$ and FER $(\mathrm{p}<0.01)$ as compared with $\mathrm{CCl}_{4}$ intoxicated group indicating the sign of amelioration.

\section{Biochemical results:}

The effect of GbE on serum liver enzyme activities (AST, ALT \& ALP), and TP levels in $\mathrm{CCl}_{4}$ intoxicated rats is illustrated in Table (2). $\mathrm{CCl}_{4}$ intoxication caused a sharp significant increase in serum AST, ALT and ALP activities $(\mathrm{p}<0.001)$, and significant reduction in serum TP level compared to control group $(\mathrm{p}<0.001)$. Administration of $\mathrm{GbE}$ to rats showed nonsignificant changes in serum liver enzyme activities, and TP level as compared to control group. Pretreatment of rats with GbE caused a marked protection evidenced by significant reduction $(\mathrm{p}<0.001)$ in serum AST, ALT and ALP enzyme activities, and significant increase ( $\mathrm{p}<0.001)$ in TP level compared to $\mathrm{CCl}_{4}$ group.

Table (3) shows the effect of GbE on lipid profile parameters in $\mathrm{CCl}_{4}$ intoxicated rats. Serum TC, TG, LDL-C and VLDL-C levels were significantly increased $(\mathrm{p}<0.001)$ along with a significant decrease in serum HDL-C levels ( $\mathrm{p}<0.001)$ in $\mathrm{CCl}_{4}$ intoxicated rats, as compared to control rats. Administration of $\mathrm{GbE}$ to rats revealed non-significant changes in all tested lipid profile parameters compared to control group. $\mathrm{GbE}$ pretreatment showed a significant improvement in the levels of lipid parameters, there was significant decrease in serum TC, TG, LDL-C and VLDL-C levels ( $\mathrm{p}<0.001)$ along with a significant increase in serum HDL-C levels $(\mathrm{p}<0.001)$ in rats group pretreated with $\mathrm{GbE}$ as compared to $\mathrm{CCl}_{4}$ group.

Effect of $\mathrm{GbE}$ on hepatic malondialdehyde (MDA) and reduced glutathione (GSH) in $\mathrm{CCl}_{4}$ intoxicated rats is presented in Table (4). Results showed that, the level of MDA in the rats' liver tissue, significantly elevated $(\mathrm{p}<0.001)$ in $\mathrm{CCl}_{4}$ intoxicated group compared to control group. On the other hand pretreatment of rats with $\mathrm{GbE}$ revealed amelioration in hepatic MDA content, since the value of MDA showed significantly reduced $(\mathrm{p}<0.001)$ as compared to $\mathrm{CCl}_{4}$ group, while the results of rats receiving GbE tended to match control value. Regarding, hepatic GSH, the results revealed significant reduction $(\mathrm{p}<0.001)$ in rats intoxicated with $\mathrm{CCl}_{4}$ as compared to control group. Pretreatment of rats with GbE markedly preserved hepatic GSH, the value of GSH near to normal levels comparing with $\mathrm{CCl}_{4}$ group, at the same time there was significant difference $(\mathrm{p}<$ 0.001) as compared with $\mathrm{CCl}_{4}$ group.

\section{Histopathological results:}

Microscopically, liver from control rat group showed the normal histological structure of hepatic lobule and portal vein without alterations Fig. (1). Liver tissues in $\mathrm{CCl}_{4}$ intoxicated rats showed focal area of hepatic necrosis associated with mononuclear cells infiltration Fig. (2) and ballooned hepatocytes and pyknosis of their nuclei Fig. (3). Moreover, vacuolar degeneration of hepatocytes (fatty change) Fig. (4). Liver tissues of rats group received GbE showed no histopathological changes Fig. (5). Pretreatment of rats with $\mathrm{GbE}$ showed apparent normal histological structure Fig. (6).

\section{Discussion:}

Liver diseases reduce people's quality of life and frequently lead them to death. The occupational exposure to chemical compounds like aliphatic hydrocarbons alters the liver structure and functions (Jaeschke, 2008). Carbon tetrachloride $\left(\mathrm{CCl}_{4}\right)$ is one of the most studied hepatotoxic compounds and is frequently used as a model of experimental liver damage (Rinco'n et al., 1999). Administration of $\mathrm{CCl}_{4}$ causes acute liver damage that mimics natural causes. It mediates changes in liver function that ultimately leads to destruction of hepatocellular membrane (De Andrade Belo et al., 2012).The hepatotoxic effect of $\mathrm{CCl}_{4}$ is due to the oxidative damage by free radical generation, and antioxidant property is claimed to be one of the mechanisms of hepatoprotective drugs (Pandit et al., 2004). G. biloba is known as an antioxidant, it shows potential in treating cerebrovascular dysfunctions and peripheral vascular disorders, in part owing to its potent antioxidant properties (Diamond et al., 2000 and McKenna et al., 2001). It can also enhance antioxidant defenses in vitro in cancer cells (Gohil and Packer, 2002). In the present investigation, $\mathrm{GbE}$ was evaluated for the 
hepatoprotective activity using $\mathrm{CCl}_{4}$ induced acute hepatotoxicity in rats.

In this Study, results showed that rats group intoxicated with $\mathrm{CCl}_{4}$ revealed significant decrease in weight gain percent, food intake and FER as compared to control group. These results were in agreement with (Venukumar and Latha, 2002, Chang et al., 2007 and Balamurugan and Muthusamy, 2008). Pretreatment of rats with GbE showed a significant increase in weight gain percent, food intake and FER as compared to $\mathrm{CCl}_{4}$ intoxicated group. These findings suggested that the extract administration has significantly neutralized the toxic effects of $\mathrm{CCl}_{4}$ and helped regeneration of hepatocytes. These observations were in perfect conformity of Farooq et al. (1997). Guo et al. (2011) reported that pretreatment with Ginkgo leaf extract significantly suppressed the effect of $\mathrm{CCl}_{4}$. These results indicate that $\mathrm{GbE}$ is a potent hepatoprotective agent against $\mathrm{CCl}_{4}{ }^{-}$ induced liver injury. On the other hand, oral administration of GbE induced slightly increase in weight gain percent, food intake and FER as compared to control group, this confirmed its safe use and agree with Dias et al. (2008) who found no significant alterations was observed in body weight gain or food consumption associated with G. biloba extract ingestion.

In the present study, following injection of $\mathrm{CCl}_{4}$ serum ALT, AST and ALP activities have dramatically significant elevation when compared to control group. These results were consistent with those studies where ALT, AST and ALP activities were significantly increased following $\mathrm{CCl}_{4}$ injection (Tirkey et al., 2005 and Anand et al., 2011). Elevated levels of serum liver marker enzymes are indicative of cellular leakage and loss of functional integrity of cellular membrane in liver (Drotman and Lawhorn, 1978), since SGPT is thought to be one of the indices of the degree of cell membrane damage and SGOT is an indicator for mitochondrial damage; mitochondria contain $80 \%$ of this enzyme (Dabba and Abdel-Rahman, 1998). This effect of $\mathrm{CCl}_{4}$ may be attributed to hepatocellular necrosis or membrane damage leads to very high levels of serum transaminases (ALT and AST) released from liver to circulation (Achliya et al., 2003). Serum ALP level on the other hand, is related to the function of hepatic cell, the increase in ALP serum level is due to increase its synthesis, in the presence of increased biliary pressure (Muriel et al., 1992).

There were significant restorations of these enzymes level by pretreatment with GbE. The reversal of increased serum ALP enzymes in $\mathrm{CCl}_{4}$-induced liver damage by the extract may be due to the prevention of the leakage of intracellular enzymes by its membrane stabilizing activity. This is in agreement with the commonly accepted view that serum levels of transaminases return to normal with the healing of hepatic parenchyma and the regeneration of hepatocytes (Thabrew and Joice, 1987). Hepatoprotective activity may be due to presence of compounds in this extract with high antioxidant capacity. Studies have shown that flavonoid (ginkgo-flavone glycosides) and terpenoid (ginkgolides and bilobalides) are the most important active substances in the G. biloba extract which have antioxidant effect (Itil and Martorano, 1995). This agrees with Ding et al. (2005) and Cha'vezMorales et al. (2010).

The liver is known to play a significant role in the serum protein synthesis, being the source of plasma albumin and fibrinogen and also the other important components like $\alpha$ and $\beta$-globulin. The metabolic biotransformation of amino acid in liver by synthesis, transamination, etc., may be impaired due to the escape of both non-proteins and protein nitrogenous substances from injured cells as mediated by a raise in the serum enzyme activities of AST, ALT and ALP. The reduction in the TP is attributed to the initial damage produced and localized in the endoplasmic reticulum which results in the loss of cytochrome P-450 enzymes leading to its functional failure with a decrease in protein synthesis and accumulation of triglycerides leading to fatty liver (Suresh Kumar et al., 2007). Pretreatment with GbE enhanced the synthesis of TP which accelerates the regeneration process and the protection of liver cells that is clearly demonstrated in the present study. Therefore, the increased level of TP in serum indicates the hepatoprotective activity. Moreover, Zhang et al. (2004) reported that GbE has a protective effect on hepatic endothelial cells and hepatic microcirculation in rats with chronic liver injury induced by $\mathrm{CCl}_{4}$, the mechanisms may 
involve its inhibition on platelet-activating factor and lipid peroxidation.

The present results revealed significant elevation in serum TC, TG, LDL-C and VLDL-C levels along with significant reduction in serum HDL-C levels in $\mathrm{CCl}_{4}$ intoxicated rats, as compared to control rats. These results were in agreement with the previous results of El-Habibi et al. (2009) and Al-Dosari (2010). $\mathrm{CCl}_{4}$ intoxication increases the synthesis of fatty acids and triglycerides from acetate, this could be attributed to $\mathrm{CCl}_{4}$ positively affects the transport of acetate into the liver cell, resulting in increased acetate availability, $\mathrm{CCl}_{4}$ intoxication also results in inhibition of synthesis of the bile acids from cholesterol which is synthesized in liver or derived from plasma lipids leading to increase cholesterol level (Boll et al., 2001). On the other hand, $\mathrm{CCl}_{4}$ lowers $\beta$ - oxidation of fatty acids and hydrolysis of triglycerides, this increases the availability of fatty acids to esterification (Lieber, 2000). The current study showed that pretreatment of rats with $\mathrm{GbE}$ resulted in significant improvement in the tested lipid profile parameters, it could be attributed to the active components of $\mathrm{GbE}$, mainly flavonoid fraction, which have many beneficial effects, and antioxidant properties (Oteiza et al., 2005 and Bhendrich, 2006).

Lipid peroxidation is one of the principal causes of $\mathrm{CCl}_{4}$-induced liver injury and is mediated by the free-radical derivatives of $\mathrm{CCl}_{4}$ (Manibusan et al., 2007). The level of lipid peroxide is a measure of membrane damage and alterations in structure and function of cellular membranes. In the present study, elevation hepatic MDA of rats intoxicated with $\mathrm{CCl}_{4}$ was observed. The increase in hepatic MDA levels leading to tissue damage and failure of antioxidant defense mechanisms to prevent the formation of excessive free radicals (Amresh et al., 2007). Pretreatment of rats with $\mathrm{GbE}$ significantly reduced the elevated levels of MDA through scavenging oxygen radicals as the extract possesses a potent antioxidant activity. Ginkgo's antioxidant activity is attributed to its ability to increase levels of free radical-scavenging enzymes and to neutralize ferryl ion-induced peroxidation ((Bridi et al., 2001 and Naik and Panda, 2007).
Glutathione is one of the most abundant tripeptide non-enzymatic biological antioxidant, its functions include removal of free radicals such as $\mathrm{H}_{2} \mathrm{O}_{2}$ and superoxide anions, maintenance of membrane protein thiols and acting as a substrate for glutathione peroxidase and glutathione reductase (Meister, 1984). In the present study, significant decrease in hepatic GSH level was observed in $\mathrm{CCl}_{4}$ intoxicated group as compared to control group. The depletion of hepatic GSH has been shown to be associated with an enhanced toxicity to $\mathrm{CCl}_{4}$ (Hewawasam et al., 2003). The increase in hepatic GSH level in the rats pretreated with GbE may be due GSH regeneration. This effect of GbE may be due to an initial reduction in hepatic peroxidative activities, thereby leading to restoration of the GSH content (Naik and Panda, 2007). These effects would also contribute to partially explain the hepatoprotective effect of GbE by inhibiting the biotransformation of $\mathrm{CCl}_{4}$ and the consequent production of free radicals (Cha'vez-Morales et al., 2010).

Histological results were in agreement with the measured activities of serum liver enzymes and provided supportive evidence for the biochemical analysis, in the current study, histopathological examination of the liver tissues showed congestion in portal vein with infiltration of mononuclear inflammatory cells, necrosis, vacuolar degeneration and kupffer cells activation in $\mathrm{CCl}_{4}$ group. Accordance to these findings, Padhy et al. (2007) observed leukocytic infiltration, centrilobular necrosis and vacuolation in $\mathrm{CCl}_{4}$ treated rats. Gupta et al. (2011) observed also fatty change, congestion in portal vein, necrosis, ballooning degeneration and loss of cellular boundaries. These finding relates with high activities of serum liver enzyme activities found in the $\mathrm{CCl}_{4}$ group in the present results. Liver sections of rats pretreated with GbE showed regeneration of hepatocytes near normal liver architecture. This may be explained by the constituents of $\mathrm{GbE}$ are scavengers of free radicals, and inhibit lipid peroxidation, thus help to maintain the integrity and permeability of cell membranes and protects cells and tissues against oxidative stress induced by free radicals (Naik and Panda, 2007). Protective effect of GbE against $\mathrm{CCl}_{4}$ induced hepatotoxicity in rats appears to be 
related to inhibition of MDA and enhancement of antioxidant enzymes in addition to free radicals scavenging activity. Therefore, the hepatoprotective action, combined with antioxidant activity, has a synergistic effect in preventing the process of initiation and progress of hepatocellular diseases.

In conclusion, the present results demonstrated that $\mathrm{GbE}$ was effective in the prevention of $\mathrm{CCl}_{4}$ induced acute toxic effects in rat liver, which were proven by biological evaluation, biochemical analysis, and further supported by the histological examinations in the liver tissues. This hepatoprotective activity is both preventive and curative. As a possible mechanism an aqueous extract of G. biloba leaf consists of many chemical constituents which could scavenge oxidative free radicals, inhibit lipid peroxidation, possess antioxidant activity and then alleviate acute liver toxicity. This absence of toxicity of GbE should be taken into account if safety measures for public health are to be implemented in response to increased ingestion of this herbal by human populations, given that $\mathrm{GbE}$ has been clinically prescribed for the treatment of various diseases. Further studies are required to isolate the active constituents in aqueous extract responsible for hepatoprotective activity and developing new drugs to treat drug/chemical-induced liver toxicity.

\section{Acknowledgment:}

I am grateful to Agri. Eng. Samir Mahmoud Abo Zeid, General Manager of specialized gardensInternational Garden - Cairo for his kindly provided the ginkgo leaves. I would like to thank Dr. Kawkab A. Ahmed, Assistant Professor of Pathology, Faculty of Veterinary Medicine, Cairo University, for her help to carry out the histopathological study of this work.

\section{Reference:}

Achliya GS, Kotgale SG, Wadodkar AK and Dorle AK (2003): Hepatoprotective activity of Panchgavya Gritha in carbon tetrachloride induced hepatotoxicity in rats. Indian $\mathrm{J}$. Pharmacol., 35:311.

Ahlemeyer $B$ and Krieglstein $J$ (2003): Neuroprotective effects of Ginkgo biloba extract. Cell Mol. Life Sci., 60: 1779-1792.
Al-Dosari MS (2010): The effectiveness of ethanolic extract of Amaranthus tricolor L.: A natural hepatoprotective agent. Am. J. Chin. Med., 38(6):1051-1064.

Allain CA, Poon LS, Chan CSG, Richmond W and Fu P (1974): Enzymatic determination of total serum cholesterol. Clin. Chem., 20:470.

Amresh G, Kant R, Zeashan H, Gupta RJ, Rao CHV and Singh PN (2007): Gastroprotective effects of ethanolic extract from Cissampelos pareira in experimental animals. J. Nat. Med., 61:323-328.

Anand KV, Anandhi R, Pakkiyaraj $M$ and Geraldine P (2011): Protective effect of chrysin on carbon tetrachloride $\left(\mathrm{CCl}_{4}\right)$-induced tissue injury in male wistar rats. Toxicol. Ind. Health, 27(10):923-933.

Balamurugan $G$ and Muthusamy $P$ (2008): Observation of the hepatoprotective and antioxidant activities of Trianthema decandra Linn.(Vallai sharunnai) roots on carbon tetrachloride-treated rats. Bangladesh J. Pharmacol., 3(2):83-89.

Bancroft D, Stevens A and Turmer R (1996): Theory and practice of histological technique, $4^{\text {th }}$ ed., Churchill Living Stone, Edinburgh, London, Melbourne. p: 47-67.

Belfied A and Goldberg DM (1971): Enzyme, 12,561. C/F: Bio-Merieux, L’Etoile, France.

Beutler E, Duron O and Kelly DO (1963): Improved method of determination of blood glutathione. J. Lab. Clin. Med., 61(5):882-888.

Bhendrich A (2006): Flavonoid-membrane interactions: possible consequences for biological effects of some polyphenolic compounds. Acta. Pharmacol. Sinica., 27: 27- 40.

Boll M, Weber LW, Becker E and Stampfl A (2001): Pathogenesis of carbon tetrachlorideinduced hepatocyte injury bioactivation of $\mathrm{CCl}_{4}$ by cytochrome P450 and effects on lipid homeostasis. Z Naturforsch C., 56(1-2):111-121.

Boonkaew $T$ and Camper ND (2004): Biological activities of Ginkgo extracts, Phytomedicine, 12: 318-323.

Bridi R, Crossetti FP, Steffen VM and Henriques AT (2001): The antioxidant activity of standardized extract of Ginkgo biloba (EGb 761) in rats. Phytother. Res., 15: 449- 451

Chang HF, Lin YH, Chu CC, Wu SJ, Tsai YH and Chao JC (2007): Protective effects of Ginkgo biloba, Panax ginseng, and Schizandra chinensis extract on liver injury in rats. The Am. J. of Chinese Medicine, 35 (6): 995-1009

Cha'vez-Morales RM, Jaramillo-Jua'rez F, Posadas del Río FA, Reyes-Romero MA, Rodri'guez-Va'zquez ML and Martı'nez- 
Saldaña MC (2010): Protective effect of Ginkgo biloba extract on liver damage by a single dose of $\mathrm{CCl}_{4}$ in male rats. Human and Experimental Toxicology, 30 (3): 209-216.

Cocchetto DM and Bjornsson TD (1983): Methods for vascular access and collection of body fluids from the laboratory rat. J. Pharm. Sci., 72 (5): 465- 492.

Dabba MH and Abdel Rahman MS (1998): Hepatoprotective activity of thymoquinone in isolated rat hepatocytes. Toxicol. Lett., 95: 23-29.

Das S, Santra A, Lahiri $S$ and GuhaMazumder DN (2005): Implications of oxidative stress and hepatic cytokine (TNF-alpha and IL-6) response in the pathogenesis of hepatic collagenesis in chronic arsenic toxicity. Toxicol. Appl. Pharmacol., 204: 18-26.

De Andrade Belo MA, Soares VE, De Souza LM, Da Rosa Sobreira MF, Cassol DM and Toma SB (2012): Hepatoprotective treatment attenuates oxidative damages induced by carbon tetrachloride in rats. Exp. Toxicol. Pathol., 64(3):155-165.

Demacker PNM, Vos-janssen HE, Hifman AGM, Vant's Lear A and Jansen AP (1980): Measurement of high density lipoprotein cholesterol in serum. Comparison of sex isolation methods combined with enzymatic cholesterol analysis. Clin. Chem., 26(13):1780.

Diamond BJ, Shiflett SC, Feiwel N, Mathei SRJ, Noskin O and Richards JA (2000): Ginkgo biloba extract: mechanisms and clinical indications. Arch. Phys. Med. Rehabil., 81: 668678.

Dias MC, Rodrigues MAM, Reimberg MCH and Barbisan LF (2008): Protective effects of Ginkgo biloba against rat liver carcinogenesis. Chemico-Biological Interactions, 173: 32-42

Ding J, Yu J, Wang C, Hu W, Li D and Luo Y (2005): Ginkgo biloba extract alleviates liver fibrosis induced by $\mathrm{CCl}_{4}$ in rats. Liver Int., 25:1224-1232.

Drotman RB and Lawhorn GT (1978): Serum enzymes are indicators of chemically induced liver damage. Drug Chem. Toxicol.,1(2):163-171. El-Habibi EM, Sirag HM and Edrees GM (2009): Comparative effect between Chitosan and Chitosan-cu complex on $\mathrm{CCl}_{4}$ induced liver damage in rats. Egypt J. Hosp. Med., 36:397- 405.

Farooq S, Ahmed I and Pathak GK (1997): In vivo protective role of Koflet (an ayurvedic preparation) against cellular toxicity caused by $\mathrm{CCl}_{4}$. J. Ethnopharmacol., 58(2):109-116.

Fossati $P$ and Prencipe L (1982): Enzymatic determination of triglycerides. Clin. Chem., 28:2077.
Friedewald WT, Levy RL and Fredrickson D (1972): Estimation of concentration of lowdensity lipoprotein cholesterol in plasma without use of the preparative ultracentrifuge. Clin. Chem., 18(6):499.

Gedik N, Kabasakal L, Sehirli O, Ercan F, Sirvanci S, Keyer-Uysal M and Sener G (2005): Long-term administration of aqueous garlic extract (AGE) alleviates liver fibrosis and oxidative damage induced by biliary obstruction in rats. Life Sci., 76:2593-2606.

Gohil $K$ and Packer L (2002): Global gene expression analysis identifies cell and tissue specific actions of Ginkgo biloba extract, EGb 761. Cell Mol. Biol., 48: 625-631.

Guo WY, Ni ZJ, Wang ZX, Fu ZR and Li RD (2011): The protective effects of Ginkgo leaf extract on $\mathrm{CCl}_{4}$-induced liver injury in mice. J. of Medicinal Plants Res., 5(11): 2361-2364.

Gupta RK, Hussain T, Panigrahi G, Das A, Singh GN, Sweety K, Faiyazuddin M. and Rao CV (2011): Hepatoprotective effect of Solanum xanthocarpum fruit extract against $\mathrm{CCl}_{4}$ induced acute liver toxicity in experimental animals. Asian Pac. J. Trop. Med., 4(12):964-968.

Han KH, Fukushima M, Ohba K, Shimada K, Sekikawa M, Chiji H, Lee CH and Nakano M (2004): Hepatoprotective effects of the water extract from Adzuki bean hulls on acetaminophen induced damage in rat liver. J. Nutr. Sci. Vitaminol., 50: 380-383

He SX, Wu B, Chang XM, Li HX and Qiao W (2004): Effects of selenium on peripheral blood mononuclear cell membrane fluidity, interleukin-2 production and interleukin-2 receptor expression in patients with chronic hepatitis. World J. Gastroenterol., 10: 3531-3533

Henry RJ (1964): Determination of total protein by colorimetric method. Clinical Chem., Harper and Row Publishers, New York. p: 181.

Hewawasam RP, Jayatilaka KA, Pathirana C and Mudduwa LK (2003): Protective effect of Asteracantha longifolia extracts in mouse liver injury induced by $\mathrm{CCl}_{4}$ and paracetamol. J. Pharm. Pharmacol., 55(10):1413-1418.

Itil $T$ and Martorano D (1995): Natural substances in psychiatry (Ginkgo biloba in dementia). Psychopharmacol. Bull., 31: 147-158

Jaeschke H (2008): Toxic responses of the liver. In: Klaassen CD (ed) Casarret \& Doull's toxicology. The science of poisons. $7^{\text {th }}$ ed. New York: McGraw-Hill, p:557-582.

Karthikeyan $M$ and Deepa $K$ (2010): Hepatoprotective effect of Premna corymbosa (Burm. f.) Rottl. \& Willd. leaves extract on $\mathrm{CCl}_{4}$ induced hepatic damage in Wistar albino rats. Asian Pacific J. of Tropical Medicine, 3(1): 17-20. 
Kwon YS, Ann HS, Nabeshima T, Shin EJ, Kim WK and Jhoo JH (2004): Selegiline potentiates the effects of EGb 761 in response to ischemic brain injury. Neurochem. Int ., 45: 157170.

Lieber CS (2000): Alcoholic liver disease: new insights on pathogenesis lead to new treatments. J. Hepatol., 32(1):113-128.

Loguercio C and Federico A (2003): Oxidative stress in viral and alcoholic hepatitis. Free Radic. Biol. Med., 34: 1-10

Manibusan MK, Odin M and Eastmond DA (2007): Postulated carbon tetrachloride mode of action: a review. J. Environ. Sci. Health C Environ Carcinog Ecotoxicol Rev., 25(3):185209.

McKenna DJ, Jones K and Hughes K (2001): Efficacy, safety, and use of Ginkgo biloba in clinical and preclinical applications. Alternative Ther. Health Med., 7: 70-86, 88-90.

Meister A (1984): New aspects of glutathione biochemistry and transport selective alterations of glutathione metabolism. Nutr. Rev., 42: 397- 400.

Mroueh M, Saab Y and Rizkallah R (2004): Hepatoprotective activity of Centaurium erythraea on acetaminophen-induced hepatotoxicity in rats. Phytother. Res., 18(5): 431- 433.

Muriel P, Garciapina T, Perez-Alvarez V and Mourelle M (1992): Silymarin protects against paracetamol-induced lipid peroxidation and liver damage. J. Appl. Toxicol., 12(6):439-442.

Naik SR and Panda VS (2007): Antioxidant and hepatoprotective effects of Ginkgo biloba phytosomes in carbon tetrachloride-induced liver injury in rodents. Liver Int., 27 :393-399.

Naik SR, Pilgaonkar VW and Panda VS (2006): Neuropharmacological evaluation of Ginkgo biloba phytosomes in rodents. Phytother. Res., 20: 901-905.

Oteiza P, Erlejman A, Verstraeten S, Keen C and Fraga $C$ (2005): Flavonoid membrane interactions: a protective role of flavonoids at the membrane surface. Clin. Dev. Immunol., 12: 1925.

Padhy BM, Srivastava A and Kumar V (2007): Calotropis procera latex affords protection against carbon tetrachloride induced hepatotoxicity in rats. J. Ethnopharmacol., 113(3): 498-502.

Pandit S, Sur TK, Jana U, Debnath PK, Sen S and Bhattacharyya D (2004): Prevention of carbon tetrachloride-induced hepatotoxicity in rats by Adhatoda vasica leaves. Indian J. of Pharmacology, 36 (5): 312-313.

Reeves PG, Nielsen FH and Fahey GC (1993): AIN-93 purified diets for laboratory rodents: Final report of the American Institute of Nutrition ad hoc writing committee on the reformulation of the AIN-76A rodent diet. J. Nutr., 123(11):1939.

Reitman S and Frankel S (1957): A colorimetric method for the determination of serum oxaloacetic and glutamic pyruvic transaminases. Am. J. Clin. Pathol., 28:56.

Rinco'n AR, Covarrubias A, PedrazaChaverri' J, Poo JL, Armenda'riz-Borunda J and Panduro A (1999): Differential effect of $\mathrm{CCl}_{4}$ on renal function in cirrhotic and noncirrhotic rats. Exp. Toxicol. Pathol., 51: 199205.

Snedecor GW and Cochron WG (1989): Statistical methods. $8^{\text {th }}$ ed. Lowa State Univ. Press, Ames, Lowa, USA.

Suresh Kumar SV, Sujatha C, Syamala J, Nagasudha B and Mishra SH (2007): Hepatoprotective activity of extracts from Pergularia daemia Forsk against carbon tetrachloride induced toxicity in rats. Phcog. Mag., 3:11.

Thabrew $M$ and Joice PA (1987): A comparative study of the efficacy of Pavetta indica and Osbeckia octanda in the treatment of liver dysfunction. Planta Med., 53(3):239 - 241.

Tirkey N, Pilkhwal S, Kuhad A and Chopra K (2005): Hesperidin, a citrus bioflavonoid, decreases the oxidative stress produced by carbon tetrachloride in rat liver and kidney. BMC Pharmacol., 5(2):1-8.

Venukumar MR and Latha MS (2002): Hepatoprotective effect of the methanolic extract of Curculigo Orchioides in $\mathrm{CCl}_{4}$-treated male rats. Indian J. Pharmacol., 34:269-275.

Wang Q, Zhao WZ and Ma CG (2000): Protective effects of Ginkgo biloba extract on gastric mucosa. Acta. Pharm. Sin., 21: 1153-1156. Yapar K, Cavusoglu K, Oruc E and Yalcin E (2010): Protective role of Ginkgo biloba against hepatotoxicity and nephrotoxicity in uraniumtreated mice. J. of Medicinal Food, 13(1): 179188.

Yoshioka T, Kawada K, Shimada T and Mori $M$ (1979): Lipid peroxidation in maternal and cord blood and protective mechanism against activated oxygen toxicity in the blood. Am. J. Obstet. Gynecol., 135:372-376.

Zhang C, Zu J, Shi H, Liu J and Qin C (2004): The effect of Ginkgo biloba extract (EGb 761) on hepatic sinusoidal endothelial cells and hepatic microcirculation in $\mathrm{CCl}_{4}$ rats. Am. J. Clin. Med., 32: 21-31.

Zhang WR, Hayashi $T$ and Kitagawa $H$ (2000): Protective effect of ginkgo extract on rat brain with transient middle cerebral artery occlusion. Neurol. Res., 22: 517-521. 
Table (1): Effect of GbE on weight gain percent, food intake and food efficiency ratio (FER) in $\mathrm{CCl}_{4}$ induced hepatoxicity in rats.

\begin{tabular}{|c|c|c|c|}
\hline Experimental groups & Weight gain percent & $\begin{array}{c}\text { Food Intake } \\
(\mathrm{g} / \mathrm{rat} / \mathrm{day})\end{array}$ & FER \\
\hline Control & $27.71 \pm 0.72$ & $19.16 \pm 0.74$ & $0.09 \pm 0.002$ \\
\hline $\mathbf{C C l}_{\mathbf{4}}$ & $\mathrm{a}^{* * *}$ & $\mathrm{a}^{* * *}$ & $\mathrm{a}^{* *}$ \\
\hline $\mathbf{G b E}$ & $12.28 \pm 0.88$ & $11.62 \pm 0.55$ & $0.068 \pm 0.006$ \\
\hline $\begin{array}{c}\text { Pretreated with } \\
\text { GbE + CCl }\end{array}$ & $26.54 \pm 1.14$ & $19.47 \pm 0.58$ & $0.086 \pm 0.006$ \\
\hline $\mathrm{a}^{*} \mathrm{~b}^{* * *}$ & $\mathrm{a}^{*} \mathrm{~b} * * *$ & $\mathrm{~b}^{* * *}$ \\
& $24.16 \pm 0.83$ & $17.31 \pm 0.57$ & $0.087 \pm 0.001$ \\
\hline
\end{tabular}

- GbE : Ginkgo biloba L. leaf extract

- $\mathrm{CCl}_{4}$ :Carbon tetrachloride.

- Each value represents the mean of 6 rats \pm SE.

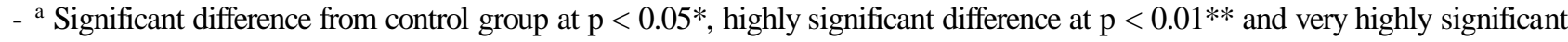
difference at $\mathrm{p}<0.001 * * *$ from control group.

- ${ }^{\text {b }}$ Significant difference between $\mathrm{CCl}_{4}$ group and $\mathrm{CCl}_{4}$ group pretreated with $\mathrm{GbE}$ at $\mathrm{p}<0.05^{*}$, highly significant difference at $\mathrm{p}<0.01 * *$ and very highly significant difference at $\mathrm{p}<0.001 * * *$.

Table (2): Effect of GbE on serum aminotransferase (ALT, AST) and alkaline phophatase (ALP) enzyme activities, as well as total protein (TP) levels in $\mathrm{CCl}_{4}$-induced hepatoxicity in rats.

\begin{tabular}{|c|c|c|c|c|}
\hline $\begin{array}{c}\text { Experimental } \\
\text { groups }\end{array}$ & $\begin{array}{l}\mathbf{A L T} \\
(\mathrm{U} / \mathrm{L})\end{array}$ & $\begin{array}{l}\text { AST } \\
(\mathrm{U} / \mathrm{L})\end{array}$ & $\begin{array}{l}\text { ALP } \\
(\mathrm{U} / \mathrm{L})\end{array}$ & $\begin{array}{c}\text { T P } \\
(\mathrm{g} / \mathrm{dl})\end{array}$ \\
\hline Control & $39.1 \pm 1.73$ & $99.99 \pm 3.99$ & $70.68 \pm 1.44$ & $6.498 \pm 0.14$ \\
\hline $\mathrm{CCl}_{4}$ & $\begin{array}{c}\mathrm{a}^{* * * *} \\
106.17 \pm 1.54\end{array}$ & $\begin{array}{c}\mathrm{a}^{* * * *} \\
215.86 \pm 3.12\end{array}$ & $\begin{array}{c}\mathrm{a}^{* * * *} \\
143.59 \pm 1.93\end{array}$ & $\begin{array}{c}\mathrm{a}^{* * * *} \\
4.54 \pm 0.15\end{array}$ \\
\hline GbE & $38.92 \pm 1.16$ & $97.98 \pm 2.02$ & $69.14 \pm 1.24$ & $6.71 \pm 0.12$ \\
\hline $\begin{array}{c}\text { Pretreated with } \\
\mathrm{GbE}+\mathrm{CCl}_{4}\end{array}$ & $\begin{array}{c}\mathrm{a}^{*} \mathrm{~b} * * * \\
46.01 \pm 2.28\end{array}$ & $\begin{array}{c}\mathrm{a}^{*} \mathrm{~b} \text { *** } \\
111.6 \pm 1.88\end{array}$ & $\begin{array}{c}\mathrm{a}^{*} \mathrm{~b}^{* * * *} \\
77.66 \pm 2.23\end{array}$ & $\begin{array}{c}\mathrm{a} * \mathrm{~b} * * * \\
5.92 \pm 0.16\end{array}$ \\
\hline
\end{tabular}

- GbE : Ginkgo biloba L. leaf extract

- $\mathrm{CCl}_{4}$ :Carbon tetrachloride.

- Each value represents the mean of 6 rats \pm SE.

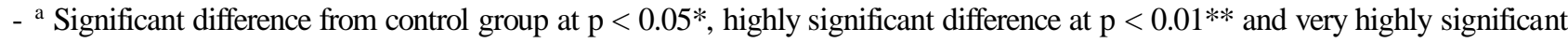
difference at $\mathrm{p}<0.001 * * *$ from control group.

- ${ }^{\mathrm{b}}$ Significant difference between $\mathrm{CCl}_{4}$ group and $\mathrm{CCl}_{4}$ group pretreated with $\mathrm{GbE}$ at $\mathrm{p}<0.05^{*}$, highly significant difference at $\mathrm{p}<0.01 * *$ and very highly significant difference at $\mathrm{p}<0.001 * * *$. 
Table (3): Effect of GbE on serum lipid profile parameters in CCl4-induced hepatoxicity in rats.

\begin{tabular}{|c|c|c|c|c|c|}
\hline $\begin{array}{c}\text { Experimental } \\
\text { groups }\end{array}$ & $\begin{array}{c}\text { TC } \\
(\mathrm{mg} / \mathrm{dl})\end{array}$ & $\begin{array}{c}\text { TG } \\
(\mathrm{mg} / \mathrm{dl})\end{array}$ & $\begin{array}{l}\text { HDL-C } \\
(\mathrm{mg} / \mathrm{dl})\end{array}$ & $\begin{array}{l}\text { LDL-C } \\
(\mathrm{mg} / \mathrm{dl}) \\
\end{array}$ & $\begin{array}{l}\text { VLDL-C } \\
(\mathrm{mg} / \mathrm{dl})\end{array}$ \\
\hline Control & $92.08 \pm 2.57$ & $86.29 \pm 2.47$ & $44.99 \pm 1.27$ & $29.83 \pm 3.33$ & $17.26 \pm 0.49$ \\
\hline $\mathrm{CCI}_{4}$ & $\begin{array}{c}\mathrm{a}^{* * * *} \\
151.25 \pm 2.24\end{array}$ & $\begin{array}{c}\mathrm{a}^{* * * *} \\
121.16 \pm 2.11\end{array}$ & $\begin{array}{c}\mathrm{a}^{* * * *} \\
33.37 \pm 1.32\end{array}$ & $\begin{array}{c}\mathrm{a}^{* * * *} \\
93.65 \pm 2.35\end{array}$ & $\begin{array}{c}\mathrm{a}^{* * * *} \\
24.23 \pm 0.42 \\
\end{array}$ \\
\hline GbE & $90.77 \pm 2.69$ & $85.13 \pm 2.62$ & $45.36 \pm 1.61$ & $28.38 \pm 2.87$ & $17.03 \pm 0.53$ \\
\hline $\begin{array}{c}\text { Pretreated with } \\
\text { GbE + CCI } \\
\end{array}$ & $\begin{array}{c}\mathrm{a}^{*} \mathrm{~b}^{* * * *} \\
102.02 \pm 2.41\end{array}$ & $\begin{array}{c}\mathrm{a}^{*} \mathrm{~b}^{* * * *} \\
94.45 \pm 2.36\end{array}$ & $\begin{array}{c}\mathrm{a}^{*} \mathrm{~b}^{* * * *} \\
40.62 \pm 1.01 \\
\end{array}$ & $\begin{array}{c}\mathrm{a}^{*} \mathrm{~b}^{* * * *} \\
42.51 \pm 3.89 \\
\end{array}$ & $\begin{array}{c}\mathrm{a}^{*} \mathrm{~b}^{* * * *} \\
18.89 \pm 0.47 \\
\end{array}$ \\
\hline
\end{tabular}

- GbE : Ginkgo biloba L. leaf extract

- $\mathrm{CCl}_{4}$ :Carbon tetrachloride.

- Each value represents the mean of 6 rats \pm SE.

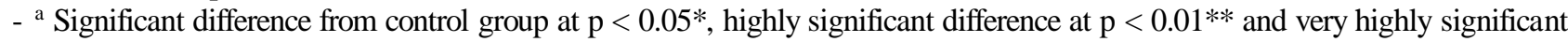
difference at $\mathrm{p}<0.001 * * *$ from control group.

- ${ }^{\mathrm{b}}$ Significant difference between $\mathrm{CCl}_{4}$ group and $\mathrm{CCl}_{4}$ group pretreated with $\mathrm{GbE}$ at $\mathrm{p}<0.05^{*}$, highly significant difference at $\mathrm{p}<0.01 * *$ and very highly significant difference at $\mathrm{p}<0.001 * * *$.

Table (4): Effect of GbE on hepatic lipid peroxide as (MDA) and reduced glutathione (GSH) in $\mathrm{CCl}_{4}$-induced hepatoxicity in rats.

\begin{tabular}{|c|c|c|}
\hline Experimental groups & $\begin{array}{c}\text { MDA } \\
(\mathrm{nmol} / \mathrm{g} \text { tissue })\end{array}$ & $\begin{array}{c}\text { GSH } \\
(\mathrm{mg} / \mathrm{g} \text { tissue })\end{array}$ \\
\hline Control & $185.6 \pm 3.01$ & $20.78 \pm 0.34$ \\
\hline CCI 4 & $\mathrm{a}^{* * * *}$ & $\mathrm{a}^{* * *}$ \\
\hline GbE & $259.17 \pm 4.08$ & $14.38 \pm 0.50$ \\
\hline $\begin{array}{c}\text { Pretreated with } \\
\text { GbE + CCI }\end{array}$ & $182.00 \pm 2.57$ & $22.84 \pm 0.95$ \\
\hline
\end{tabular}

- GbE : Ginkgo biloba L. leaf extract

- $\mathrm{CCl}_{4}$ :Carbon tetrachloride.

- Each value represents the mean of 6 rats \pm SE.

- ${ }^{a}$ Significant difference from control group at $\mathrm{p}<0.05^{*}$, highly significant difference at $\mathrm{p}<0.01^{* *}$ and very highly significant difference at $\mathrm{p}<0.001 * * *$ from control group.

- ${ }^{\mathrm{b}}$ Significant difference between $\mathrm{CCl}_{4}$ group and $\mathrm{CCl}_{4}$ group pretreated with $\mathrm{GbE}$ at $\mathrm{p}<0.05^{*}$, highly significant difference at $\mathrm{p}<0.01 * *$ and very highly significant difference at $\mathrm{p}<0.001 * * *$. 


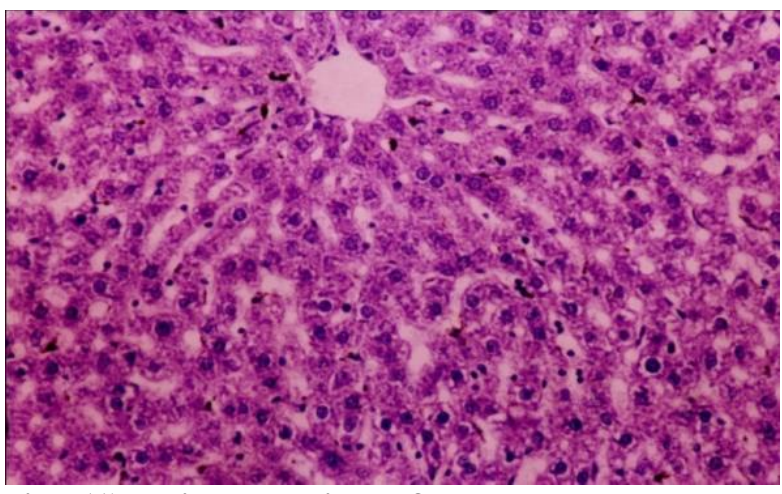

Fig. (1): Liver section of control rats showed normal histological structure of hepatic lobule and portal vein without alterations.

(H\&E stain $\mathrm{x} 200)$

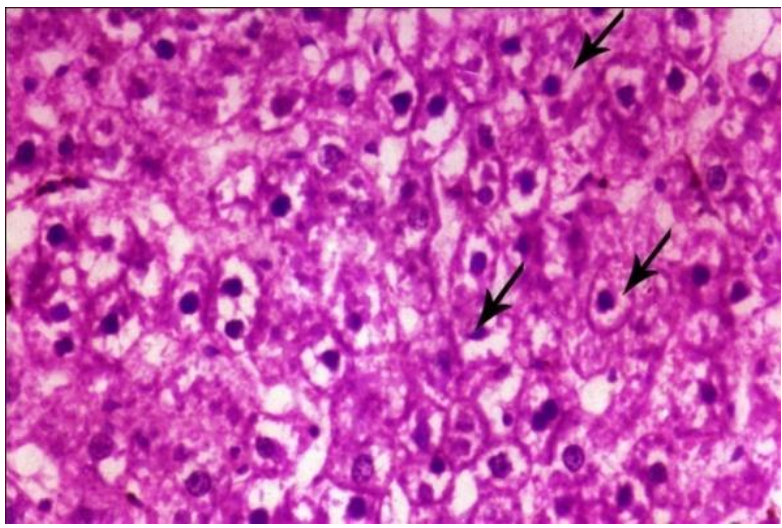

Fig. (3): Liver section of $\mathrm{CCl}_{4}$ intoxicated rats showed ballooned hepatocytes and pyknosis of their nuclei (arrow).

(H\&E stain x200)

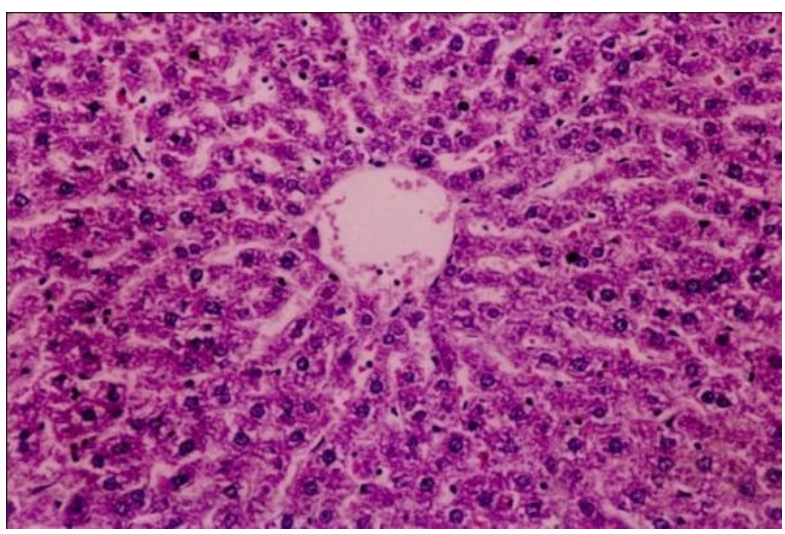

Fig. (5): Liver section of rats received GbE showed no histopathological changes.

(H\&E stain x200)

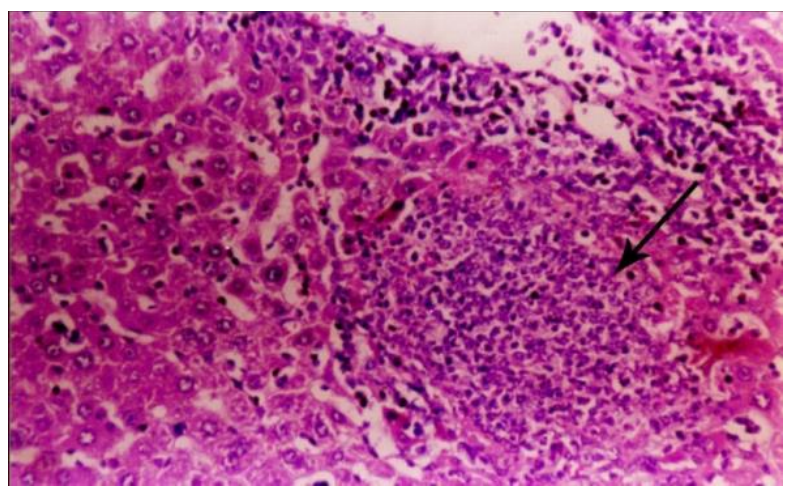

Fig. (2): Liver section of $\mathrm{CCl}_{4}$ intoxicated rats showed focal area of hepatic necrosis associated with mononuclear cells infiltration (arrow). $\quad$ (H\&E stain x200)

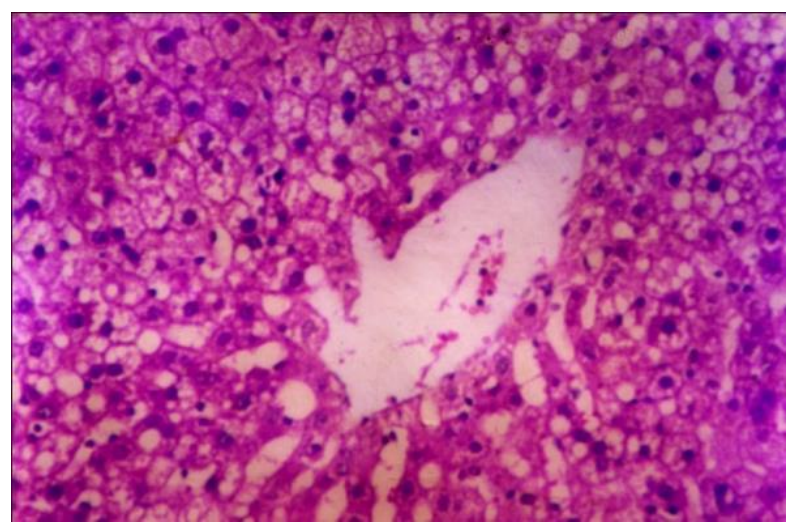

Fig. (4): Liver sections of $\mathrm{CCl}_{4}$ intoxicated rats showed vacuolar degeneration of hepatocytes (fatty change). (H\&E stain x200)

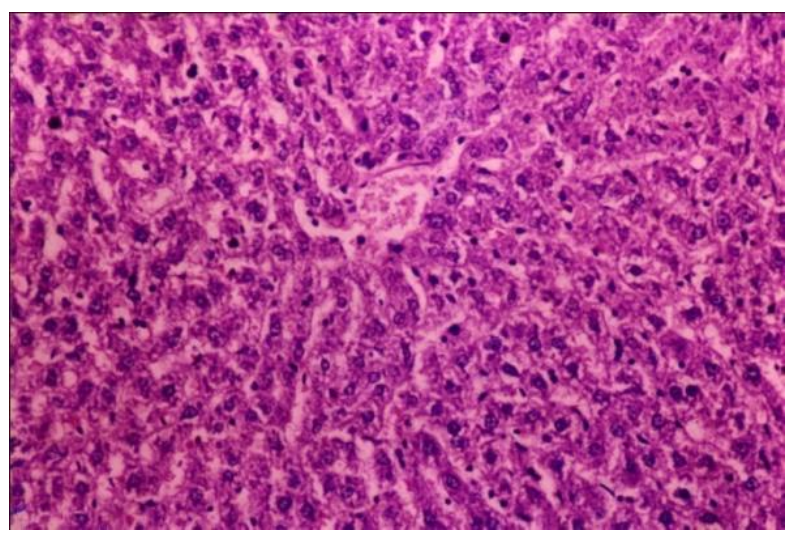

Fig. (6): Liver section of rats group pretreated with GbE showed apparent normal histological structure. (H\&E stain $\mathrm{x} 200)$ 


\title{
تأثير المستخلص المائي لأوراق نبات الجنكوبيلوبا علي التسمم الكبدي الحاد

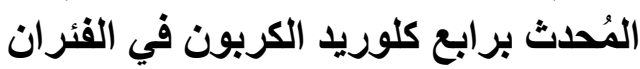

\author{
هالة عبد الرحمن حسن خطاب \\ قسم التغذية و علوم الأطعمة_ كلية الإقتصـاد المنزلي- جامعة حلوان \\ الملخص العربي
}

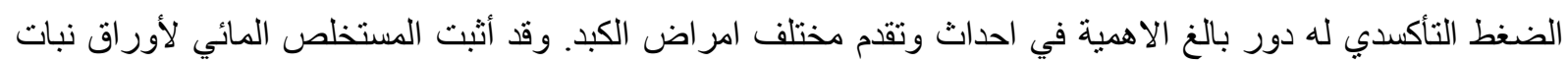

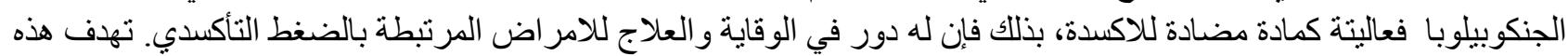

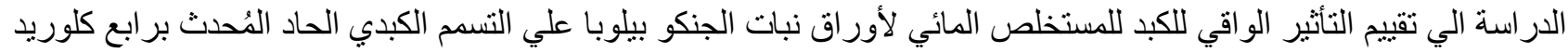

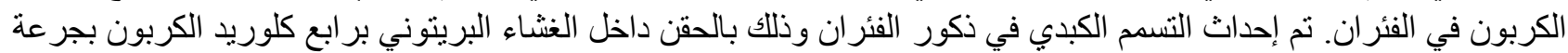

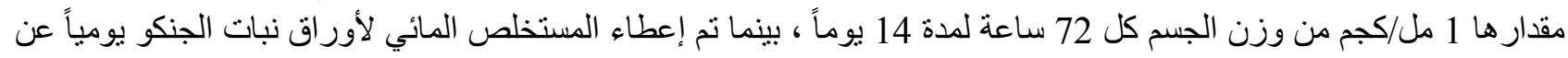

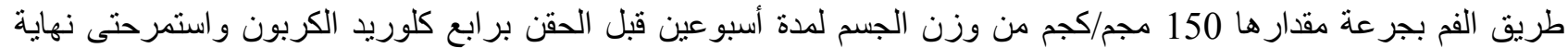

أظهرت النتائج أن الحقن برابع كلوريد الكربون قد أحدث تلف حاد في الكبد, حيث وجد إرتفاع ذو دلالة إحصائية في

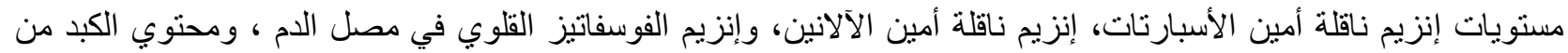

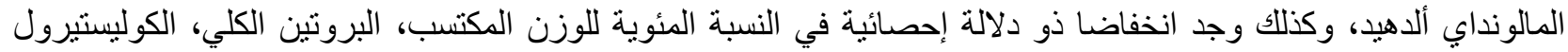

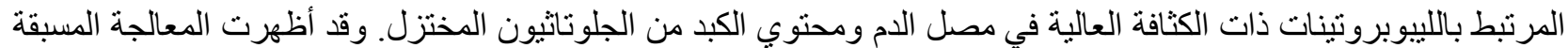

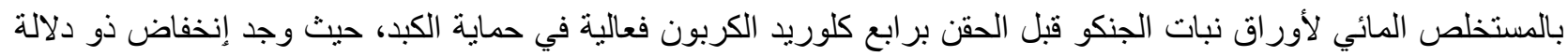

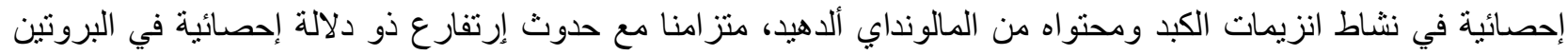

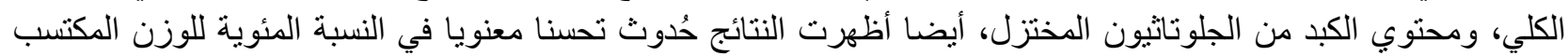

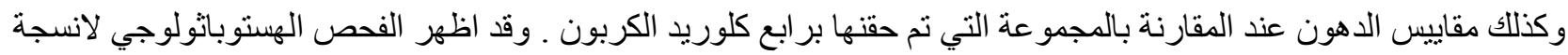

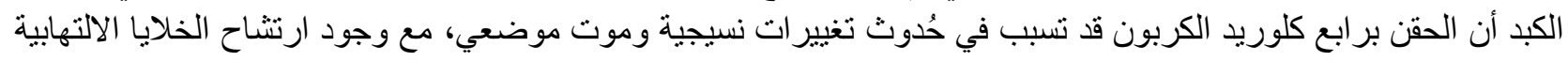

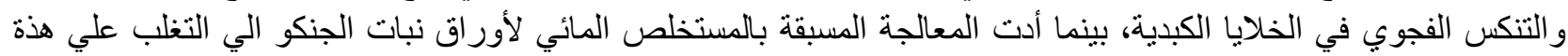

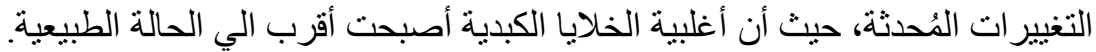

تثثير نتائج هذه الدراسة إلى أن التأثير الواقي للكبد للمستخلص المائي لاوارق نبات الجنكو ضد التباد التلف التأكسدي

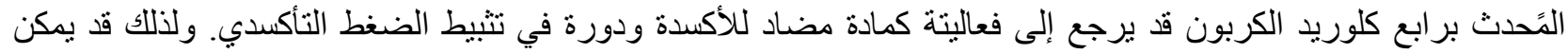
أستعمال هذا المستخلص المائي لاور اق نبات الجنكو في المستحضر الئرات الدوائية ومكملات الاغذية لفائدتة في التقليل من السمية الكبدية.

الكلمات المفتاحية: نبات الجنكو بيلوبا، المستخلص المائي، ذكور الفئران، رابع كلوريد الكربون، أنزيمات الكبد، مقاييس الدهون، المالونداي ألدهيد، الجلوتاثيون المختزل، التأثير الو اقيلي. 